\title{
Evaluation of Design and Operation Basis of the Smear Test Station
}

by

C. M. Lunsford (contact)

Westinghouse Savannah River Company

Savannah River Site

Aiken, South Carolina 29808

D. J. Hutsell

DOE Contract No. DE-AC09-96SR18500

This paper was prepared in connection with work done under the above contract number with the U. S. Department of Energy. By acceptance of this paper, the publisher and/or recipient acknowledges the U. S. Government's right to retain a nonexclusive, royalty-free license in and to any copyright covering this paper, along with the right to reproduce and to authorize others to reproduce all or part of the copyrighted paper. 


\section{DISCLAIMER}

This report was prepared as an account of work sponsored by an agency of the United States Government. Neither the United States Government nor any agency thereof, nor any of their employees, makes any warranty, express or implied, or assumes any legal liability or responsibility for the accuracy, completeness, or usefulness of any information, apparatus, product or process disclosed, or represents that its use would not infringe privately owned rights. Reference herein to any specific commercial product, process or service by trade name, trademark, manufacturer, or otherwise does not necessarily constitute or imply its endorsement, recommendation, or favoring by the United States Government or any agency thereof. The views and opinions of authors expressed herein do not necessarily state or reflect those of the United States Government or any agency thereof.

This report has been reproduced directly from the best available copy.

Available for sale to the public, in paper, from: U.S. Department of Commerce, National Technical Information Service, 5285 Port Royal Road, Springfield, VA 22161,

phone: (800) 553-6847,

fax: (703) 605-6900

email: orders@ntis.fedworld.gov

online ordering: http://www.ntis.gov/ordering.htm

Available electronically at http://www.doe.gov/bridge

A vailable for a processing fee to U.S. Department of Energy and its contractors, in paper, from: U.S. Department of Energy, Office of Scientific and Technical Information, P.O. Box 62,

Oak Ridge, TN 37831-0062,

phone: (865)576-8401,

fax: (865)576-5728

email: reportsbadonis.osti.gov 


\section{DISCLAIMER}

Portions of this document may be illegible in electronic image products. Images are produced from the best available original document. 


\section{DEFENSE WASTE PROCESSING FACILITY \\ EVALUATION OF DESIGN AND OPERATION BASIS OF THE SMEAR TEST SYSTEM (U)}

PREPARED BY: Dale J. Hutsell, 704-4S Cognizant Engineer DWPF Cognizant Engineering

\section{UHCONTROLLED COPY ISSUED BY DWPF-SDCS}

APPROVED BY:

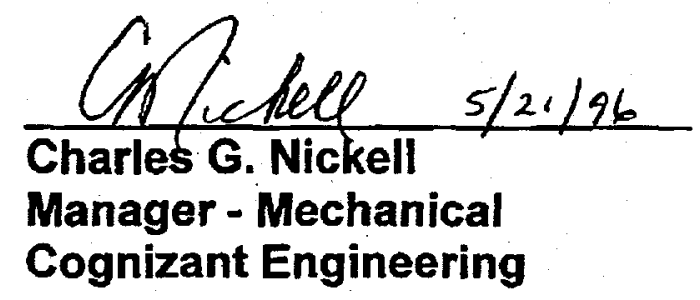

M-ESR-S-00009 Revision 1

ENGINEERING DOC. CONTROL-SRS

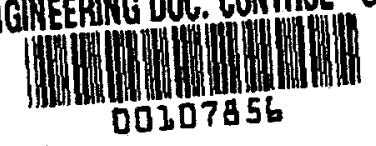

May 14,1996

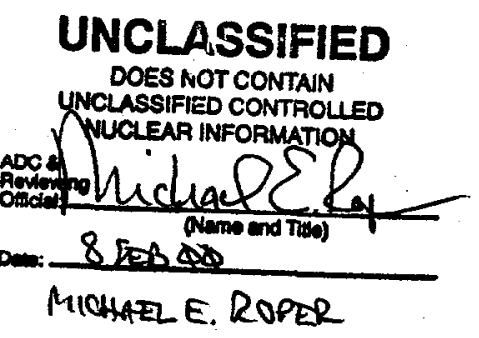




\section{Introduction}

The Smear Test Stations (STS) provide the means for measuring the effectiveness of the canister decontamination process. This is accomplished by collecting remotely smeared samples of the canister's exterior to verify that radioactive contamination is below Department of Energy prescribed limits which are based on the Department of Transportation wipe limits (49 CFR, 173.443). The DOE/DOT requirements prescribe a 300 square centimeter area of an object's surface be wiped which is a representative sample of the object. This standard applies to external surfaces of shipping casks. While the canister is not exposed to the environment like a shipping cask, this standard was applied to provide conservative limits for onsite storage (alpha radiation is less than: 220 dpm/100 square centimeters, beta \& gamma radiation is less than: 2200 $d p m / 100$ square centimeters). It has been demonstrated that the STS remote smearing technique, using a Master-Slave Manipulator and a smear tool, is equivalent to, if not better than, the traditional hand smearing technique (WSRCRP-91-598, "Smearing DWPF Waste Glass Canisters - II, Results and Recommendations"). Each STS will smear 1000 square centimeters of the canister surface area. Therefore, the STS method for smearing is adequate and in accordance with 49 CFR, 173.443 .

The canisters undergo two separate smear tests: one after the canister decontamination process (Canister Decontamination Cell Smear Test Station, or CDC/STS); and the other after the final canister closure weld (Weld Test Cell Smear Test Station, or WTC/STS). The purpose of the CDC/STS is to ensure the effectiveness of the canister decontamination process and to limit the potential spread of transferable contamination. The purpose of the WTC/STS is to provide final verification that the external canister surface is free of transferable contamination before transporting the canister to the Glass Waste Storage Building for onsite storage.

The smear test equipment at each Station consists of:

- a canister turntable which provides both lift and rotation, and is controlled by separate Local Control Station (LCS) located next to the respective Station's shielded window;

- a pair of Master-Slave Manipulators (MSMs) which Operations uses to perform the smearing of the canister surface;

- a shielded window for remote viewing of the smearing operation; 
- a pneumatic transfer system, using pressurized air as the motive force, for transferring new smears into the Stations from the radio bench hood, and used smears out of the Stations back to the radio bench hood for isotopic contamination counting (these transfer systems are controlled by two LCSs contained in one console located next to the radio bench hood);

- a set of smear tools which are designed both to allow the MSMs to conduct a smear with 3 to 10 pounds of force to a standard $11 / 4$ " diameter smear pad affixed to foam-backed tape, and to travel in the pneumatic transfer systems while protecting the smear pad; and

- $\quad$ a radio bench hood which services both Stations and provides a controlled environment both to receive used smears from the Stations for gross betagamma counting, and to perform subsequent packaging for more accurate counting by the Radiation Control Operations.

In addition, the CDC/STS also contains a trolley to move the canister from the STS turntable to the pedestal, located at the north end of the CDC/STS tunnel, for retrieval by the WTC crane. This trolley is also controlled by the same LCS which controls the CDC/STS turntable.

Each station will take a minimum of 5 smears per canister. These smears will be taken such that all decon chamber blast zones will be checked (See figure A1 attached).

The first smear will be taken across the bottom of the canister while it is suspended above the smear test station by the in-cell crane. This smear is to cover both the concave portion of the canister bottom as well as the edge (approximately $200 \mathrm{~cm}^{2}$, see Figure A1, Smear \#1). If the smear exceeds DOE/DOT requirements, then separate $100 \mathrm{~cm}^{2}$ smears will be taken on the bottom concave and edge (See figures A1, Smears \#1A, \#1B).

The second smear will be taken with the turntable in the raised position and will be taken from the lowest point reachable by the MSM to the approximate center line of the canister. This will cover blast zones 6 and 7 (See figure A1 attached) and will be approximately $200 \mathrm{~cm}^{2}$. If the smear exceeds the DOE/DOT requirements, a separate $100 \mathrm{~cm}^{2}$ smear will be taken on each blast zone (See Figure $A 1$, Smears \#2A, \#2B) and compared to the DOE/DOT requirements. This information will determine which canister decontamination system blast zone may require maintenance before the canister is reblasted.

Smear three is similar to smear two with the exception that the turntable will be fully lowered so that blast zones 4 and 5 can be checked. This smear will include the canister side label (See Figure A1, Smears \#3, \#3A, \#3B). 
The fourth smear (approximately $200 \mathrm{~cm}^{2}$ ) will be taken across the canister shoulder, shoulder label, neck and under the flange of the canister (blast zones 2 and 3). If this smear exceeds the DOE/DOT limits, separate $100 \mathrm{~cm}^{2}$ smears will be taken on the shoulder, neck and under the flange of the canister (See Figure A1, Smears \#4, \#4A, \#4B, \#4C).

The final (fifth) smear will be a $100 \mathrm{~cm}^{2}$ smear taken on top of the canister (See Figure A1, Smear \#5).

Radiological Controls personnel (RCO) will count all smears to determine if the smears are less than the DOE/DOT limits $\left(220 \mathrm{dpm} / 100 \mathrm{~cm}^{2}\right.$ alpha and 2200 $\mathrm{dpm} / 100 \mathrm{~cm}^{2}$ beta gamma). The canister will not be allowed to proceed until RCO has determined that all smears are less than these limits. 
FIGURE A1

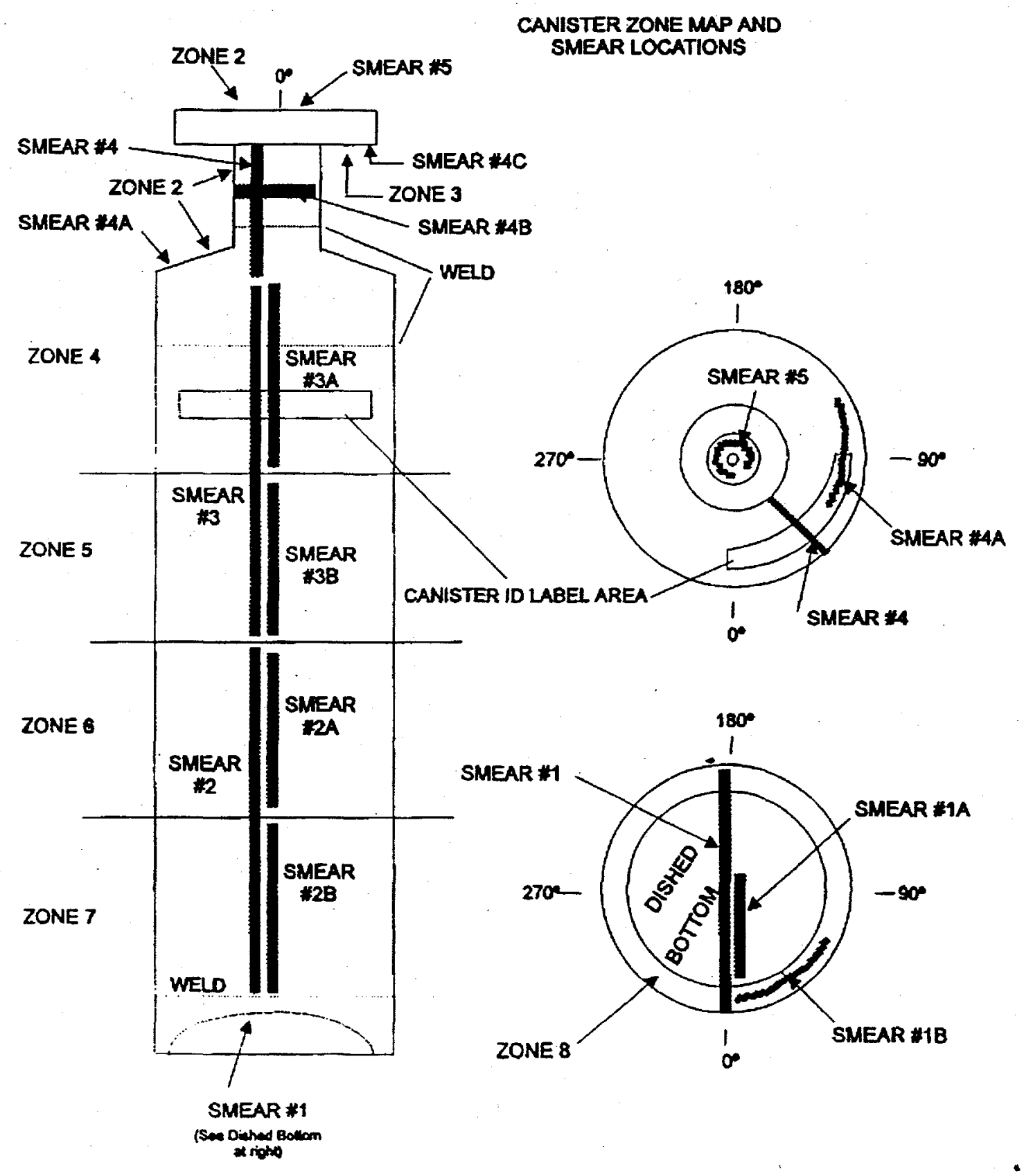

